\title{
«Norge ligger på dette området langt fremme i forhold til de fleste land»: Utdanning for bærekraftig utvikling i Norge og Sverige
}

\author{
Ingerid S. Straume \\ Universitetsbiblioteket, Universitetet i Oslo, Norge
}

\begin{abstract}
Sammendrag
Gjennom 1970- og 80-tallet var det ikke uvanlig at pedagogiske miljøer i Norge engasjerte seg i sosiale bevegelser og politiske saker, som miljø- og fredsbevegelsen. Dagens politisk-sosiale saker, som utdanning for bærekraftig utvikling (UNESCO), har fått langt mindre oppmerksomhet i fagfeltet, selv om Norge holder en høy profil i internasjonal sammenheng. I denne artikkelen sammenligner jeg Norges og Sveriges tilnærming til FN-prosesser som Agenda 21 og FNs tiår for utdanning for bærekraftig utvikling, og diskuterer mulige forklaringer på den svake oppfølgingen av disse prosessene i Norge. Et forhold som framheves av flere forskere, er den tette koblingen mellom norsk politikk og utvinningen av olje og gass, der økt oppmerksomhet omkring økologiske og økonomiske sammenhenger vanskelig lar seg forene med fortellingen om det norske oljeeventyret. Slik oppmerksomhet vil kunne lede til beklemmende spørsmål som blir vanskelige å håndtere i skolen. Utgangspunktet for artikkelen er likevel at det ligger et stort, ubrukt potensial i pedagogikkfaget til å belyse og arbeide med denne type spørsmål.
\end{abstract}

Nøkkelord: Utdanning for barekraftig utvikling; ESD; Agenda 21; komparative studier; miljøpedagogikk

\begin{abstract}
Back in the 1970 s and 80 s it was quite common to observe a strong commitment to social movements and political causes in educational settings. The socio-political issues of our current time, however, receive much less attention. In a Norwegian context, this lack is notable with respect to education for sustainable development (ESD) as promoted by UNESCO - although Norway tends to hold a high profile internationally in these matters. In this article I compare the respective approaches of Norway and Sweden to United Nations' initiatives such as Agenda 21 and the Decade for Education for Sustainable Development, and discuss possible explanations for the weak implementation of these processes in Norway. One possible explanation, pointed out by several researchers, is the close connection between Norwegian politics and the extraction of oil and gas. Indeed, increased attention to the relationship between ecological and economic factors would disturb the narrative of the miraculous, Norwegian «oil adventure», leading to disturbing questions that might become difficult to handle in a school setting. Even so, the article builds on
\end{abstract}

^Korrespondanse: Ingerid S. Straume, HumSam-biblioteket, Avdeling for fag og studier, Universitetet i Oslo, Postboks 1009 Blindern, 0317 Oslo. E-post: Ingerid.straume@ub.uio.no

C 2016 Ingerid S. Straume. This is an Open Access article distributed under the terms of the Creative Commons Attribution 4.0 International License (http://creativecommons.org/licenses/by/4.0/), allowing third parties to copy and redistribute the material in any medium or format and to remix, transform, and build upon the material for any purpose, even commercially, provided the original work is properly cited and states its license. 
the premise that there is a great, unused potential in the educational tradition to elucidate and work on this type of questions.

Keywords: Education for sustainability; Agenda 21; Norway; Sweden; environmental education

Received: May 2016; Accepted: September 2016; Published: December 2016

\section{Innledning}

I nær sagt alle diskusjoner om vern av miljø og bærekraftig utvikling, i FN-systemet, nasjonale policyprosesser og den økofilosofiske litteraturen, har utdanning en helt sentral betydning. FNs satsing på Education for Sustainable Development (ESD), ${ }^{1}$ som på norsk har fått navnet Utdanning for Bærekraftig Utvikling (UBU), omfatter hele utdanningsløpet, og skal kunne gienspeiles i alt fra undervisningsmateriale til lærerutdanning (UNECE strategi for hållbar utveckling, 2008). FNs arbeid med utdanning for bærekraftig utvikling har pågått helt siden 1970-tallet. ${ }^{2}$ Spørsmålet som melder seg da, er hvorfor dette arbeidet ikke har fått større gjennomslag i norsk skole og høyere utdanning?

For å nærme meg et svar, skal jeg gå historisk til verks. Med utgangspunkt $\mathrm{i}$ internasjonale policyprosesser for bærekraftig utvikling mer generelt, nedfelt $\mathrm{i}$ dokumentene Var Felles Framtid og Agenda 21, vil jeg ta for meg den norske oppfølgingen av Rio-prosessen, som det internasjonale ESD-arbeidet bygger på. Det er spesielt interessant å se hvor forskjellig Norge og Sverige har forholdt seg til oppfølgingen av de aktuelle FN-prosessene. Der Sverige har forankret arbeidet med ESD på alle nivåer i utdanningssystemet, og lagt en bred definisjon til grunn, har Norge fulgt en mer tradisjonell oppskrift for miljøundervisning i naturfag.

Analysen bygger på dokumentstudier av perioden fra 1987 (Vår Felles Framtid) fram til i dag, med spesiell vekt på publikasjoner fra det strategiske forskningsprogrammet ProSus, ${ }^{3}$ som ble opprettet ved Universitetet i Oslo for å følge opp Rio-prosessen for miljø og utvikling i Norge. I tidligere arbeider (Straume 2001, 2002, 2005) har jeg tatt for meg den offentlige samtalen om miljø- og utviklingspolitikk i Norge, med utgangspunkt i Agenda 21s oppfordringer om dialog mellom myndigheter, organisasjoner og lokalbefolkning for å skape en mer bærekraftig utvikling. ${ }^{4}$ Denne artikkelen trekker linjer framover i tid for å se om det kan være

\footnotetext{
${ }^{1}$ ESD omtales ofte også som Education for Sustainability.

${ }^{2}$ I 2015 vedtok FN 17 såkalte bærekraftsmål som erstatning for Tusenårsmålene. Utdanning (quality education) er bærekraftsmål nummer fire. Dette er gode nyheter for UNESCO, som er ansvarlig for å følge opp ESD, og som nå har fått en sterkere forankring i FN-systemet som helhet. ${ }^{3}$ «Program for Research and Documentation for a Sustainable Society». Forfatteren var tilknyttet ProSus som hovedfagstudent i 1999-2000, og skrev det som på den tid ble betraktet som en i overkant kritisk oppgave om implementeringen av Lokal Agenda 21 i Norge (se Lindseth \& Bjørnæs, 2002).

${ }^{4}$ I disse arbeidene identifiserte jeg en tendens til avpolitisering i den norske miljøpolitikken. Lignende analyser har senere vært gjort av Martiniussen (2012) og i Sverige, av Knutsson (2011).
} 
noen sammenheng mellom den nasjonale oppfølgingen av Agenda 21 og myndighetenes tilnærming til utdanning for bærekraftig utvikling. Som vi skal se, fins det klare paralleller mellom den mangelfulle politiske innsatsen for bærekraftig utvikling i Norge på 1990-tallet og oppfølgingen av FNs tiår for utdanning for bærekraftig utvikling et drøyt tiår senere (2005-2014).

Det er de store linjene som vektlegges i framstillingen. I første del tar jeg for meg bakgrunnen for ESD og oppfølgingen i Norge. Deretter går jeg inn på prosessene rundt oppfølgingen av Agenda 21 og Lokal Agenda 21, som var ganske annerledes i Norge og Sverige. På bakgrunn av dette viser jeg hvordan innføringen av ESD i Sverige mer eller mindre sømløst kunne bygge videre på grunnlaget som var lagt med Agenda 21. Etter en kort diskusjon av Norges posisjon i disse spørsmålene, tar jeg for meg en mer utvidet forståelse av pedagogikkens rolle for bærekraftig utvikling.

\section{Utdanning for barekraftig utvikling i FN-systemet og Norge}

Når historien om utdanning for bærekraftig utvikling fortelles, er det vanlig å starte med FNs første miljøkonferanse som fant sted i Stockholm i 1972. Konferansen har blitt en merkestein for utdanning i miljøspørsmål, og komiteen anbefalte å opprette et internasjonalt program for miljøpedagogikk (environmental education, EE) som senere ble endret til utdanning for bærekraftig utvikling, eller ESD. For Norges vedkommende er det kanskje vel så opplagt å starte med Brundtlandkommisjonens rapport, Var felles framtid, som ble lansert i 1987. Med denne rapporten ble uttrykket bærekraftig utvikling presentert i sin mest kjente form, som en «utvikling som imøtekommer dagens behov uten å ødelegge muligheten for at kommende generasjoner skal få dekket sine behov» (Verdenskommisjonen for Miljø og Utvikling, 1987, s. 42). Vår felles framtid ble fulgt opp med en stor, internasjonal konferanse om miljø og utvikling i Rio de Janeiro i 1992. Rio-konferansen (også kalt Earth Summit) ga opphav til en rekke viktige initiativer, som Agenda 21, den første klimakonvensjonen (forløper til Kyotoprotokollen), konvensjonen for biologisk mangfold og ikke minst, et internasjonalt samarbeid for utdanning for bærekraftig utvikling (ESD). ${ }^{5}$ Det ble også holdt et stort parallellarrangement i Rio kalt Global Forum, der 17000 representanter fra frivillige organisasjoner deltok med konsultativ status. Et forslag som ble fremmet på Rio-konferansen av daværende generalsekretær Boutros Boutros-Ghali var deklarasjonen Earth Charter, som et tilsvar til utfordringene fra Vår Felles Framtid med stor vekt på betydningen av utdanning (se for eksempel Gadotti, 2010). ${ }^{6}$ Earth Charter ble ansett å være for radikalt til å oppnå bred tilslutning, og i stedet ble den såkalte Rio-deklarasjonen (Rio Declaration on Environment and Development) vedtatt av de 178 deltakende regjeringene. To tiår senere, i 2002, vedtok FNs generalforsamling tiåret for utdanning for bærekraftig

\footnotetext{
${ }^{5}$ Utdanning for bærekraftig utvikling var tema for kapittel 36 i Agenda 21.

${ }^{6}$ Initiativtakere til Earth Charter var Mikhael Gorbatsjov og Maurice Strong, som medlemmer av Roma-klubben. I ettertid har arbeidet med Earth Charter fortsatt. Se for eksempel fournal of Education for Sustainable Developments temanummer om Earth Charter Education, september 2010, 4(2).
} 
utvikling (Decade for Education for Sustainable Development, DESD) som varte fra 2005 til 2014. Dette er det mest ambisiøse og omfattende initiativet for utdanning for bærekraftig utvikling så langt (Sinnes \& Eriksen, 2015), der motivet var erkjennelsen av at «utdanning er en uunnværlig bestanddel for å oppnå bærekraftig utvikling» (UNESCO, 2008).

Utdanning for bærekraftig utvikling legger til grunn Vår Felles Framtids brede utviklingsbegrep, der miljøproblemer også har sosiale og økonomiske dimensjoner som fattigdom/utviklingsproblemer. Dette gjør ESD til et grunnleggende tverrfaglig emne med politiske dimensjoner, noe som giør det til et spennende - men kanskje også kontroversielt - område for pedagogikk og fagdidaktikk.

Norge var en del av samarbeidet om tiåret for ESD, som ble koordinert av FNs organ for utdanningsspørsmål, UNESCO. Tiåret er nå over, og oppsummert i en rekke rapporter og artikler (Huckle \& Wals, 2015; Jucker \& Matar, 2015). For Norges vedkommende er det vel trygt å si at tiåret ikke har satt de helt store spor (Andresen, Høgmo \& Sandås, 2015; Laumann, 2007; Sinnes \& Eriksen, 2015). Selv om det ble laget en slags strategi som senere ble revidert og noe utvidet (Kunnskapsdepartementet, 2012), ble denne aldri nedfelt $\mathrm{i}$ noen handlingsplan eller som lærings- og kompetansemål for skolene. Ansvaret for å følge opp tiåret med praktiske tiltak ble lagt til «Den naturlige skolesekken»: et sekretariat, nettsted og ressurssenter ved Naturfagsenteret (Nasjonalt senter for naturfag i opplæringa) tilknyttet Universitetet i Oslo. Her har det vært mulig for skoler å søke midler for å styrke sin satsing på undervisning om miljøspørsmål. Mer enn 600 skoler har fått midler fra Den naturlige skolesekken gjennom de første 5 åra (Sjaastad, Carlsten, Opheim \& Jensen, 2014).

Norges oppfølging av ESD-tiåret er oppsummert og vurdert i forbindelse med en internasjonal evaluering (Andresen et al., 2015). Til tross for at mye ligger til rette for en integrert og bred satsing i Norge - blant annet Kunnskapsløftets vekt på lokalt tilpasset læreplanarbeid, en rekke formuleringer i læreplanens generelle del og en lang tradisjon med uteskole - har overgangen til utdanning for bærekraftig utvikling vært «utfordrende», hevder forskerne, især når det gjelder å utvide perspektivet fra det «snevert» naturfaglige til de mer tverrfaglige og integrerende arbeidsformer og perspektiver som kjennetegner utdanning for bærekraftig utvikling. Utfordringene ligger både på policy-, ledelses- og faglig nivå. Når det gjelder satsingen gjennom Den naturlige skolesekken, skriver forskerne at programmet ikke har lykkes i å implementere UBU i flertallet av skolene. I stedet har en stor andel av deltakerskolene satset på tradisjonelle uteskoleprosjekter, mens viktige kvaliteter ved utdanning for bærekraftig utvikling, som samarbeid med lokale aktører om lokale utfordringer, har vært vanskelig å få til (Andresen et al., 2015, s. 250). ${ }^{7}$ Det samme gjelder tverrfaglig undervisning og læring på skolene, der flertallet av de deltakende lærerne har vært naturfaglærere. Frivillige organisasjoner er også viktige aktører i arbeidet med UBU. Om disse sier forskerne:

Also the majority of the NGOs that have collaborated with schools are mainly concerned with outdoor recreation or nature management. Few projects have been concerned with social themes such as inclusion, democracy, or social justice, and

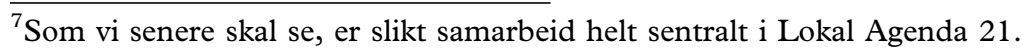


this indicates that many Norwegians tend to understand ESD within the frame of natural science (Andresen et al., 2015, s. 250).

I tidligere faser av prosjektet var det et større innslag av eksperter og didaktikere fra ulike fag i ressursgruppa for Den naturlige skolesekken, som samfunnsvitenskap og mat og helse, men disse faggruppene forsvant etter hvert ut av prosjektet, mens naturfagene ble værende (Andresen et al., 2015).

Det er mange interessante aspekter ved dette saksfeltet, og bare noen få kan berøres her. En interessant dimensjon gjelder behovet for støtte og forankring hos skoleledelse og skoleeier for å lykkes med denne type utviklings- eller lokalt læreplanarbeid. Disse spørsmålene blir diskutert i NIFUs evaluering (Sjaastad et al., 2014) samt i en studie fra Den naturlige skolesekken, og vil ikke tas opp her. En annen viktig faktor er den manglende sammenhengen mellom læreplanens generelle del og læreplaner i fagene som gjør det vanskelig å implementere arbeidet med UBU. Andresen et al. (2015) peker blant annet på at den generelle delen (fra L97), som inneholder en rekke betraktninger om mål for opplæringen, verdier, samfunnsdiagnoser og årsakssammenhenger med relevans for UBU, i liten grad blir brukt i lokalt læreplanarbeid. Som Sinnes og Jegstad (2011) har observert, kan det være svært vanskelig for lærere å oppfylle de generelle målene og arbeide med utdanning for bærekraftig utvikling i en travel skolehverdag, selv om mange ønsker å gjøre dette.

Ved åpningen av tiåret for UBU og lansering av den norske tresiders strategien, sa daværende leder for den norske UNESCO-kommisjonen, Astrid Nøklebye Heiberg at «kunnskap om bærekraftig utvikling skal gjennomsyre all undervisning $\mathrm{i}$ den norske skole» (Sinnes \& Jegstad, 2011, s. 249). I ettertid oppsummerer Sinnes og Eriksen (2015) at der tiåret for ESD/UBU ikke har klart å få gjennomslag med å endre utdanningssystemets verdier eller skape nye, sammenhengende strukturer og arbeidsmåter, har OECD, med sine PISA-tester og rangeringer, lykkes desto bedre. Dette er et viktig punkt, og en mulig forklaring - skjønt den kan ikke forklare forskjellene mellom Norge og Sverige som skal beskrives lenger ned. Det er allikevel et faktum at utdanning for bærekraftig utvikling retter seg inn mot en annen type samfunnsutvikling enn det som kjennetegner nyliberalismens mål og virkemåter - der OECD er en viktig drivkraft - og dette påvirker selvsagt også skoleledelsens og skoleeiers muligheter til å styre skolene i en bærekraftig retning. Sannsynligvis er de politiskøkonomiske rammene minst like avgjørende for skolenes arbeid med UBU som manglende ressurser eller vilje til å handle. For dersom utdanningssystemet virkelig skulle gå inn for en bærekraftig utvikling, ville det fått store konsekvenser både med hensyn til faglig innhold og for organiseringen av selve utdanningssystemet (se for eksempel Kahn, 2010).

I neste avsnitt skal vi nærme oss et svar på hvorfor det har vært så vanskelig for Norge å ta inn over seg utdanning for bærekraftig utvikling - i motsetning til vårt naboland Sverige. Historien, slik jeg leser den her, begynner med FN-konferansen i Rio de Janeiro og den internasjonale «handlingsplanen for det 21. århundre», Agenda 21, som på mange måter startet det hele. Oppfølgingen av Rio-prosessen i Norge kan etter mitt syn være et viktig - og underbelyst - bakteppe for å forstå hvorfor det 
egentlig aldri har blitt noen satsing på utdanning for bærekraftig utvikling, det være seg i norske skoler, barnehager eller høyere utdanning, selv om det utvilsomt har vært en del gode prosjekter og enkelttiltak.

\section{Agenda 21 i Norge: Opp som en løve, ned som en skinnfell}

Ved Rio-konferansen i 1992 sluttet Norge seg til en handlingsplan for det 21. århundre kalt Agenda 21. Dette var en avtale mellom 178 regjeringer om å følge opp en rekke temaer knyttet til bærekraftig utvikling, blant annet gjennom tett samarbeid mellom myndigheter, næringsliv og frivillige organisasjoner. Dette representerte noe nytt i policy-sammenheng, og var knyttet til både målstyring og New Public Management (se for eksempel Lafferty, Aall \& Seippel, 1998). I årene etter Rio skulle hvert land identifisere de viktigste nasjonale og lokale utfordringene, og utarbeide en strategi for å følge opp målene fra Agenda 21 på nasjonalt nivå. I Norge ble det laget en stortingsmelding som sammenfattet målene fra Rio for Stortinget (Miløøverndepartementet, 1992). Det skulle imidlertid ta 11 år før det ble laget en nasjonal strategi.

Et kapittel i Agenda 21 som har blitt viktig i ettertid er det korte kapittel 28, kalt «Lokal Agenda 21» eller bare LA21. Teksten, som utgjør kun 3 av 700 sider, dreier seg om hva som kan og bør gjøres på lokalt nivå, altså i kommunene, for å skape en mer bærekraftig utvikling. Gjennom medvirkning og dialog skulle man skape lokale tilsvar til globale problemer, og utarbeide lokale handlingsplaner for en bærekraftig utvikling som involverte og forpliktet ulike aktører. Partene i dialogene skulle være myndigheter, næringsliv, organisasjoner og vanlige borgere. To grupper framholdes som spesielt viktige i denne sammenheng: ungdom og kvinner.

Sverige var tidlig ute med å lage en nasjonal Agenda 21, og satset først og fremst på kommunene. I rapporten til oppfølgingskonferansen «Rio + 10» ble det fastslått at alle svenske kommuner på en eller annen måte arbeidet med Lokal Agenda-prosesser (Nationalkommitén för Agenda 21 och Habitat, SOU 2003: 31). Agenda 21 ble i Sverige en anledning til å integrere ulike hensyn og prosesser som lokaldemokrati, ungdomsaktiviteter, integrering og frivillig arbeid, etter hvert også sysselsetting og lokalt klimaarbeid. Agenda 21-arbeidet ble dermed formet og tilpasset flere nasjonale og lokale behov, som arbeidsledighet, lokaldemokrati, helse og byutvikling. Komiteen bak rapporten knytter de ulike virksomhetene til Sveriges lange tradisjon med lokaldemokrati, delaktighet og folkbildning. Når det gjelder skolering, ble det gjennomført «[e]tt mycket omfattande utbildningsarbete ... såväl inom de kommunala organisationerna som riktat mot en bredare allmänhet. Studieförbund gick tidigt ut och erbjöd Agenda 21-studiecirklar till organisationer och allmänhet» (s. 22). Et stort antall foreninger og organisasjoner var også involvert og pådrivere $i$ arbeidet. I 1998 oppga 97 prosent av kommunene at man gjorde «konkreta insatser för att engagera medborgarna i processen», og i mai 2002 hadde over 70 prosent av kommunestyrene vedtatt en Lokal Agenda 21-plan (s. 24).

I Norge ble det ingen slik allmenn implementering, men det fantes en del offentlige og halvoffentlige initiativer, som Prosjekt Bærekraftige Lokalsamfunn fra 
1996, den såkalte Fredrikstaderklæringen (1998), ${ }^{8}$ samt stiftelsene Idébanken og Miljøheimevernet (senere Grønn Hverdag). På nasjonalt nivå ble oppfølgingen av Agenda 21 først lagt til Miljøverndepartementet, men ble etter hvert flyttet til Utenriksdepartementet og deretter til Finansdepartementet. Det ble også opprettet et forskningsprogram - Program for Research and Documentation for a Sustainable Society: ProSus - som skulle følge opp Norges forpliktelser i henhold til Agenda 21 og andre, internasjonale avtaler som dreide seg om omlegging til et bærekraftig samfunn. ProSus sammenlignet blant annet satsingene i Norge og Sverige, og fant store forskjeller i graden av implementering. I Sverige ble Agenda 21 raskt forankret på nasjonalt nivå med en strategi og en rekke nasjonale og kommunale tiltak, også i skoleverket. Hvordan gikk det så i Norge? Etter at Agenda 21 hadde forsvunnet fra den norske offentlighetens lys, oppsummerte forskere ved ProSus Norges innsats med følgende uttrykk: high ambitions - disjointed follow-up - inconsequential results (Lafferty, Knudsen \& Mosvold Larsen, 2007), eller sagt med et folkelig uttrykk: opp som en løve, ned som en skinnfell. Den mangelfulle implementeringen skyldtes flere ting. Blant annet vurderte myndighetene at man allerede var kommet veldig godt i gang med arbeidet for en bærekraftig utvikling gjennom MIK-reformen (Miljøvern i Kommunene) fra 1992. MIK tilførte øremerkede tilskudd til miljøvernkonsulenter i alle norske kommuner. Med dette ble det ansett at Lokal Agenda 21-arbeidet allerede hadde en forankring i lokalforvaltningen (Aall, 2000). Lokal Agenda 21 fikk dermed ikke egne kontorer eller sekretariater, som i Sverige, men miljøvernkonsulentene hadde også mange andre oppgaver, som kartlegging av vannressurser, biologisk mangfold, forurensningssaker og så videre. Da øremerkingen ble avviklet i 1997, forsvant imidlertid disse stillingene som egen kategori i de aller fleste kommuner, og mange gikk inn i teknisk etats øvrige arbeid.

En annen grunn til at Norge betraktet seg selv som et slags foregangsland, var den aktive deltakelsen $\mathrm{i}$ internasjonale forhandlinger, ikke minst gjennom Gro Harlem Brundtlands innsats med Vår felles framtid. I internasjonal sammenheng er Norge, ifølge ProSus' forskere, en «distinkt anomali» (Lafferty et al., 2007). Dette henger sammen med den store avstanden mellom retorikk og realitet - ord og gjerning som etter forskernes mening er mye større her enn de fleste andre vestlige land (Lafferty et al., 2007, s. 185). I en tidlig fase var norske politikere (og NGO-ledere) høyt profilerte internasjonalt, både i forberedelsene til, og under, Rio-konferansen. Det ble også laget to ambisiøse stortingsmeldinger som bygde på innholdet i Vår felles framtid og Agenda 21, men ingen av disse ble fulgt opp av praktisk politikk; likevel hadde norske politikere en oppfatning av at de var godt i rute: «After initially claiming that Norway already was a 'league leader' in promoting [sustainable development] at the local level, it was not until 1996 that the government took a closer look at what was going on in the rest of the world - and finally initiated a support programme for LA21» (Lafferty et al., 2007, s. 186). Denne innsatsen for LA21 var sen, men solid, etter forskernes mening, og avgrenset til perioden

\footnotetext{
${ }^{8}$ Fredrikstaderklæringen er en oppfordring fra (og til) norske kommuner, fylkeskommuner og organisasjoner om å gå sammen for å følge opp Agenda 21 på lokalt og regionalt nivå.
} 
1997-2001. Det som da skjedde, var at den nye Bondevik-regjeringen faset ut de igangsatte initiativene (s. 182).

Gjennom tiåret etter Rio, fra 1992 til 2002, utviklet det seg en «dobbelt», norsk profil med hensyn til bærekraftig utvikling, der landet var «very active and morally pretentious in international environment-and-development arenas, and increasingly passive and non-consequential in fronting and promoting [sustainable development] at home» (Lafferty et al., 2007, s. 186). Den svake viljen til å følge opp målene fra Rio forklarer forskerne først og fremst med den stadig mer viktige petroleumssektoren i norsk økonomi. Men etter påtrykk fra miljøbevegelsen, og fordi Norge faktisk hadde forpliktet seg til å følge opp Rio-erklæringen, kom det omsider en oppfølging fra nasjonalt hold da fristen kom for å rapportere til Rio +10 (World Summit for Sustainable Development). Få uker før konferansen i Johannesburg i 2002 ble den første strategien for bærekraftig utvikling lansert av Utenriksdepartementet, som nå hadde overtatt ansvaret for oppfølgingen (Utenriksdepartementet, 2002). Denne strategien ble kraftig kritisert av miljøorganisasjoner og forskere, blant annet for å være utydelig og mangle prioriteringer og fordi prosessen fram mot strategien var alt annet enn involverende (Lafferty, Nordskag \& Aakre, 2002). Strategien var sterkt preget av datidens mål om økoeffektivisering, som gikk ut på å produsere mer effektivt og slik redusere belastninger på miljøet, og målene som skulle sikres innenfor miljømessig forsvarlige rammer, var økonomisk og sosial velferd - også for Norge - der oljeutvinning var en del av bildet (Straume, 2005).

Hva skjedde så med denne strategien? Allerede året etter var ansvaret flyttet til Finansdepartementet, som nå skulle innføre prinsippene fra Agenda $21 \mathrm{i}$ offentlig forvaltning. Finansdepartementet lanserte en Nasjonal Handlingsplan for Bærekraftig Utvikling i 2003. Selv om prosessen denne gang var mer inkluderende, har heller ikke handlingsplanen blitt implementert ifølge Lafferty et al. (2007). I tillegg hadde det nå skjedd noe med selve bærekraft-begrepet - grunnet en iboende ambivalens som kritikere hadde advart om helt fra starten (se f.eks. Lafferty \& Langhelle, 1995) - nemlig at forståelsen nå var direkte koblet til økonomisk barekraft over tid (Straume, 2005). I den nasjonale handlingsplanen betød dette at evnen til å utføre miljøtiltak var avhengig av en sterk norsk økonomi, noe som innebar å utvinne olje og gass for å bygge opp et rikt pensjonsfond (Oljefondet) og deretter bruke avkastningen av disse pengene på miljøtiltak. Bærekraftig utvikling viste også direkte til pensjoner (forstått som bærekraft over generasjoner) og annen «bærekraftig» virksomhet $\mathrm{i}$ ordets aller snevreste betydning. I forlengelsen av handlingsplanen ble det utarbeidet et omfattende sett med indikatorer for å måle utviklingen på en rekke policy-områder (Finansdepartementet, 2005). Denne rapporteringen utgiør nå et eget kapittel i nasjonalbudsjettet, der de ulike departementene rapporterer sine resultater i henhold til bærekraftsindikatorene. Rapporteringen blir i sin tur mindre spesifikk for hvert år som går, og er heller ikke knyttet til noen sammenhengende strategi eller handlingsplan for bærekraftig utvikling som sådan (Lafferty et al., 2007).

Med innlemmelsen i nasjonalbudsjettet kan vi kanskje si at fortellingen om Agenda 21 i Norge nådde sitt endepunkt. Den andre nasjonale strategien for bærekraftig utvikling ble lansert av den rød-grønne regjeringen som del av nasjonalbudsjettet $\mathrm{i}$ 
2008 (Finansdepartementet, 2008). I forordet fra finansminister Kristin Halvorsen står det at «Regjeringen har bestemt at Norge skal være et foregangsland i arbeidet med en bærekraftig utvikling». Siden den tid har Agenda 21 mer eller mindre forsvunnet fra norsk offentlighet. Følgende graf (se figur 1), hentet fra Nasjonalbibliotekets oversikt over frekvensen av ord og uttrykk brukt i norske aviser, viser utviklingen fra 1992 til 2013:

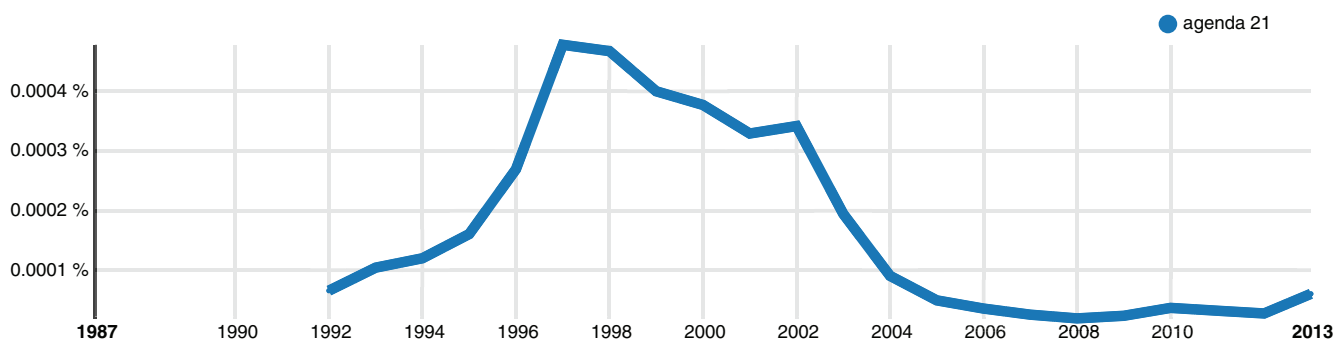

Figur 1. Frekvensen av uttrykket Agenda 21 i norske aviser 1992-2013. Hentet fra Nasjonalbiblioteket. 2015. NB N-gram. URL: http://www.nb.no/sp_tjenester/beta/ngram_1/

Arbeidet med «bærekraftig utvikling» på nasjonalt nivå er i dag i økende grad knyttet til sektorspesifikke former for bærekraft, ikke minst i form av kvalitetssikringssystemer (se for eksempel Holm, 2015). Men selv om det aldri ble laget noen handlingsplan for bærekraftig utvikling - i betydningen fra Rio - som ble iverksatt i Norge, fortsatte arbeidet med klima, miljø og bærekraftig utvikling under de to rød-grønne regjeringene ledet av Jens Stoltenberg (2005-2013). Også her skjedde det vesentlige omdefineringer av feltet, blant annet ved at miljø- og klimapolitikken ble koblet sammen med utviklingspolitikk da Miljødepartementet ble slått sammen med et nyopprettet Utviklingsdepartement, noe som gjorde det mulig å «drive klimapolitikk over utviklingsbudsjettet» (Vibe, Gloppen \& Rakner, 2014, s. 170). ${ }^{9}$ Den rød-grønne regjeringen opprettet også en egen seksjon i Utenriksdepartementet som skulle arbeide med å integrere miljø-og utviklingsarbeid, altså bærekraftig utvikling - i andre land (Utenriksdepartementet, 2009). Norske politikere, spesielt sosialøkonomen Jens Stoltenberg, har som kjent vært sterke tilhengere av å «ta utslippskuttene» i land med lavere prisnivå enn her, fordi dette var mest effektiv bruk av penger. ${ }^{10}$

\section{Lokal Agenda 21 - et godt grunnlag for ESD}

Det lokale arbeidet med Agenda 21 i Norge kom sent i gang, men ble lenge ansett som den mest lovende oppfølgingen av Rio-prosessen (Aall, 2000). Tilnærmingen med konsultasjonsprosesser om lokale utfordringer og samarbeid om løsninger lå godt til rette i Norge, med sine mange halvstatlige organisasjoner, NGO'er med

\footnotetext{
${ }^{9}$ En lignende endring er gjennomført i Sverige.

${ }^{10}$ For en kritisk gjennomgang av norsk klimapolitikk gjennom FNs klimakvotesystem, se Martiniussen (2013).
} 
statsstøtte og en, i store trekk, korporativ struktur (Strømsnes \& Selle, 1996). I den mest aktive fasen, 1997-2001, ble det lagt stor vekt på læringsprosesser og konsultasjon mellom myndigheter, sivilsamfunn og næringsliv for å oppfylle målene i Agenda 21. En grundigere satsing og oppfølging av disse ambisjonene kunne vært et godt grunnlag for videre arbeid med UBU i form av samvirke mellom skolen og ulike lokale aktører.

Anne Bregnballes forskning på prosjektet Bærekraftige Lokalsamfunn (1996-99) antyder hvilket potensial som fantes i Lokal Agenda 21 dersom hensikten hadde blitt oppfylt: et politisk medvirkningsprosjekt for en bærekraftig utvikling med utgangspunkt i et lokalsamfunn (Bregnballe, 2005, 2007). Målet for prosjektet, formulert i den nasjonale handlingsplanen for Lokal Agenda 21, var å «etablere dialoger mellom befolkning og offentlige myndigheter om miliø- og utviklingsproblematikken som skulle føre til konkrete handlinger i en bærekraftig retning på alle nivåer i samfunnet» (Bregnballe, 2005, s. 1). Hensikten med dialogene var at "[p]roblemstillinger, hindringer og mulige tiltak skulle defineres $\mathrm{i}$ en gjensidig læringsprosess mellom befolkning og lokale og nasjonale myndigheter» (Bregnballe, 2005, s. 1).

Bregnballe studerte et delprosjekt kalt Grønne Familier, ${ }^{11}$ der 54 familier i en norsk småby skulle delta i slike dialoger. Ifølge henne gikk deltakerne inn i prosjektet som høyt motiverte og engasjerte, men fikk ikke anledning til å bruke sitt engasjement. Prosjektet som sådan var preget av store ord, men små handlinger - begrenset til søppelsortering og forbrukeratferd - og en forutinntatthet overfor deltakerne som hindret dialog. I stedet for å utveksle og utvikle kunnskap, ble den relevante kunnskapen definert som eksperters kunnskap, og «dialog» ble redusert til informasjon og forsøk på motivasjon, ovenfra og ned. Deltakerne ble konstituert som individer som skulle opplyses, de hadde liten anledning til å møte hverandre, og de fleste forlot prosjektet i løpet av det første halvåret, skuffet over den snevre tilnærmingen til et komplekst og viktig saksfelt. Bregnballes intervjuer (som viser det motsatte av prosjektets offisielle rapporter) vitner om en lokalbefolkning som ønsket å arbeide for en mer bærekraftig utvikling i sitt lokalsamfunn, men ble hindret av myndighetenes forutinntatthet og mangel på dialog. Resultatet var at «[t]he global dimension disappeared totally, and so did the idea of making changes in society» (Bregnballe, 2007, s. 79).

Prosjektledelsen, på sin side, vurderte dette og de sju andre delprosjektene som en suksess, med ett forbehold: at det var vanskelig å få engasjert befolkningen (Bregnballe, 2007, s. 80). Ifølge Bregnballe var det en tendens hos prosjektledelsen (godt hjulpet av forskerne som ledet evalueringen, og nasjonale myndigheter) til å klandre befolkningen for at det var så vanskelig å innføre nødvendige endringer i bærekraftig retning. Denne tendensen til å individualisere, redusere og avpolitisere miljø- og utviklingsproblematikken var til stede $i$ en rekke tiltak og handlingsplaner i perioden, og var på mange måter karakteristisk for den norske tilnærmingen til Lokal Agenda 21 (Straume, 2002).

\footnotetext{
${ }^{11}$ Må ikke forveksles med Miljøheimevernets prosjekt med samme navn.
} 
I 2002 var anbefalingene endret fra ProSus' side. I rådgivende publikasjoner tok man nå til orde for å oppgi intensjonene om involvering og gjensidige læreprosesser - slik ProSus tidligere hadde anbefalt - da ønsket om bred deltakelse nå ble betraktet som en hindring snarere enn en forutsetning for å oppnå de ønskede målene (Bjørnæs \& Nordland, 2002). Dette er også tidspunktet da Lokal Agenda 21-perioden regnes som avsluttet i Norge (Lafferty et al., 2007).

\section{ESD i Sverige}

I motsetning til Norge, har Sverige ikke lagt ned sine LA21-initiativer, men videreført dem i ulike former, som lokalt klimaarbeid og utdanning for bærekraftig utvikling (eller utbildning for hållbar utveckling, UHU). Med en sterk forankring både i kommunene og på nasjonalt nivå, har det tilsynelatende vært relativt ukontroversielt å arbeide med bærekraftig utvikling i barnehager, skoler, høgskoler og universiteter. Svenske skoler har også anlagt et bredere, mer systemisk perspektiv enn det rent natur- og miljøfaglige (se for eksempel Östman \& Östman, 2013). Landet regnes i dag som et foregangsland når det gjelder utdanning for bærekraftig utvikling - men det skal nevnes at også Sverige har forskere som synes det går for langsomt med å integrere ESD i hele utdanningsløpet.

Noe av det som skiller den svenske og den norske satsingen på ESD er forankringen på høyeste nivå av utdanningssystemet. Sverige har blant annet hatt en nasjonal forskerskole for utdanning og bærekraftig utvikling ved Universitetet i Uppsala, og det svenske Vetenskapsrådet har finansiert en rekke forskningsprosjekter for å studere implementeringen av ESD i utdanningsløpet. En egen SOU om utdanning for bærekraftig utvikling kom i 2004, med tittelen Att lära för hållbar utveckling (Utbildningsdepartementet, SOU 2004:104). Utvalget fikk i oppdrag å «kartlegge og nyansere hvordan utdanningssystemer på alle nivåer arbeider for økonomisk, sosial og miljømessig bærekraftig utvikling». Ifølge innledningen har utdanning en «framskutt rolle» i den nasjonale strategien for bærekraftig utvikling, og regjeringen har «även inrättat ett särskilt kansli i statsrådsberedningen med ansvar för att samordna arbetet med hållbar utveckling i samtliga departement och vara pådrivande i det nationella och internationella arbetet» (s. 11). I motsetning til Norge, der ansvaret for å følge opp Agenda 21 nå ligger hos en avdeling i Finansdepartementet med ansvar for nasjonalbudsjettet, har Sverige altså opprettet et organ hvis oppdrag er å være aktiv overfor alle regjeringens departementer.

I forbindelse med avslutningen av UNESCOs tiår for ESD i 2014 ble det laget en rapport, ${ }^{12}$ forfattet av fire organisasjoner: Svensk avdeling av UNESCO, Uppsala universitet (SWEDESD), ${ }^{13}$ WWF Sverige og Det svenske høgskolerådet. Her oppsummeres erfaringer fra et drøyt tiårs arbeid med ESD/UHU, og 32 anbefalinger

\footnotetext{
${ }^{12}$ Rapporten til UNECE (United Nations Economic Commission for Europe) gir en god oversikt over Sveriges ulike satsinger på ESD: http://www.unece.org/fileadmin/DAM/env/esd/8thMeetSC/ Sweden_Country_Report.pdf

${ }^{13}$ SWEDESD, Swedish International Centre of Education for Sustainable Development er finansiert av SIDA som tilsvarer norske NORAD: http://swedesd.uu.se/digitalAssets/430/430292_3recommend ations.pdf
} 
gis for Sveriges videre arbeid i det såkalte Global Action Programme for ESD. Det mest interessante er kanskje at dokumentet er et produkt av konsultasjonsprosesser med en lang rekke aktører fra offentlig og frivillig sektor. Som det heter i denne oppsummeringen (på side 18): «As Sweden has come quite far in integrating ESD into the curriculum, such experiences are important to share internationally». Sverige deltar da også $\mathrm{i}$ en rekke arrangementer omkring ESD, og oversetter alle viktige internasjonale policydokumenter, noe Norge sjelden gjør.

Sverige har i tillegg et nasjonalt nettverk for læring for bærekraftig utvikling som ble opprettet tidlig på 1990-tallet, ${ }^{14}$ med tilsluttede nettverk for skole, universiteter, barnehager osv. Det finnes også ulike priser for skoler som ønsker å konkurrere om å være mer bærekraftige. En rekke universitetsmiljøer arbeider tverrfaglig med tematikken, blant annet ved Gøteborgs Universitet, Chalmers, Høgskolan i Malmø og Uppsala (CDU og SWEDESD). Uppsala huser også CEMUS, som er et studentdrevet senter med tverrfaglige kurser i diverse miljørelaterte emner og eksperimentelle læringsformer. I tråd med Rio-prosessen og LA2 1 foregår det også en rekke små og store samarbeidsprosjekter mellom NGO'er, forskere og praktikere. Östman og Östman (2013) trekker fram en rekke av disse, og konkluderer med at ESD i Sverige kan tjene som:

... a good example of how important the interplay between top-down and bottomup processes can be for developing effective ESD. Both are needed in order to make progress. The commitment of teachers, teacher trainers, researchers and stakeholders has been crucial for the success of ESD in Sweden, but without the support of a strong policy, this success would not have been possible (Östman \& Östman, 2013, s. 106).

Satsingen på ESD i Sverige er med andre ord omfattende og integrert, og målet om bærekraftig utvikling er forankret på høyeste nivå i forvaltningen. Bredden, mangfoldet og interessen i Sverige står i relativt grell kontrast til hvordan utfordringen fra Rio er blitt mottatt i Norge.

\section{Hvorfor så vanskelig i Norge?}

Det er rimelig å anta at den aktive oppfølgingen av Agenda 21 i Sverige har gitt en helt annen beredskap og nærhet til bærekraftig utvikling i svenske lokalsamfunn enn det som var tilfelle i Norge. Men spørsmålet gjenstår hvorfor Agenda 21 ble implementert mye raskere og grundigere i Sverige enn her. Det er selvsagt flere grunner til de store forskjellene mellom de to landenes satsing. En åpenbar forklaring, som flere har pekt på, er den stadig sterkere bindingen til petroleumsindustrien i norsk økonomi og politikk gjennom den aktuelle perioden (Eide, Elgesem, Gloppen \& Rakner, 2014; Lafferty et al., 2002). Ved utvinning og eksport av olje og gass, har den norske staten bygd opp Oljefondet (Statens pensjonsfond utland), som igjen investerer i ulike virksomheter i en rekke land - også såkalt skitten

\footnotetext{
${ }^{14} \mathrm{http}$ :/www.unesco.se/utbildning/utbildning-for-hallbar-utveckling/larande-for-hallbar-utveckling-lhu/
} 
utvinningsvirksomhet, som skiferolje og tjæresand (Klein, 2014). Dette forholdet giør det selvfølgelig vanskelig, ja, touchy, å berøre temaer som bærekraftig utvikling, klimaendringer og lignende på en inngående og forpliktende måte. At det kan finnes en slik sammenheng underbygges også av forskning som viser at bekymring for klimaendringer er mindre blant aktører i land som tjener på petroleumsvirksomhet (Sandvik, 2008). På samme måte som Sverige tilpasset sin Agenda 21-oppfølging til nasjonale behov (integrering, arbeidsledighet og byutvikling) kan vi altså si at Norge tilpasset sin tilnærming ved å tone ned motstridende mål og uforenlige virkelighetsoppfatninger (se også Norgaar, 2011).

En annen forskjell gjelder kultur. Der den norske natur- og miljøverntradisjonen har hatt en identitetsskapende rolle, med røtter til 1800-tallets folkebevegelser og nasjonalisme (Gundersen, 1996) har den svenske nasjonale identiteten vært knyttet mer til det moderne samfunnet, og mindre til det romantisk-nasjonale. Dermed er det kanskje mindre grad av konflikt mellom det å være «grønn» og å være «moderne» i Sverige enn i Norge. En tredje faktor kan rett og slett være at norske utdannings- og skoleforskere ikke har vært like opptatt av tematikken som i for eksempel Sverige, Storbritannia eller USA. Norge har likevel vært en aktiv aktør i det internasjonale arbeidet for utdanning for bærekraftig utvikling, både før og etter Brundtlandkommisjonen og Rio-konferansen i 1992, der betydningen av læring for sosial endring for alvor kom på FNs dagsorden. Når det gjelder implementering her hjemme, har vi altså vært langt mer tilbakeholdne - men dette gjenspeiles i liten grad i den offentlige selvforståelsen.

Bakerst i Norges strategi for barekraftig utvikling (Finansdepartementet, 2008) fins et kort avsnitt om UBU (én side). Her står det at «kunnskap er en helt sentral forutsetning for å lykkes i arbeidet med en bærekraftig utvikling, og skoler og andre utdanningsinstitusjoner kan her gi viktige bidrag» (s. 82). Den noe overraskende oppfølgingen lyder: «Norge ligger på dette området langt fremme i forhold til de fleste land». Man kunne kanskje forvente at dette $\mathrm{i}$ så fall hadde gjenspeilt seg $\mathrm{i}$ utdanningssystemet, for eksempel ved landets største universitet? Men da det ble gjort en kartlegging av «miljørelevante studier» ved Universitetet i Oslo i 2011, meldte det Utdanningsvitenskapelige fakultet at det ikke hadde noen slike studier (Grønt UiO, 2011). ${ }^{15}$ Først i 2015-16 begynte arbeidet for å integrere UBU i lærerutdanningen ved landets største universitet, og det er i skrivende stund fortsatt uvisst hvordan gjennomslaget vil bli. ${ }^{16}$

Når det gjelder historien om Norges oppfølging av FNs satsing på ESD/UBU, er denne en ganske klar parallell til oppfølgingen av Agenda 21 og bærekraftig utvikling mer generelt. I Norge er tiltakene spredte og snevert orienterte, mens i Sverige er de mer omfattende, integrerte og bredt forankret. I en tidlig fase ble det i Norge laget ambisiøse dokumenter, der utdanning var en viktig faktor for bærekraftig utvikling

\footnotetext{
${ }^{15} \mathrm{http} / /$ www.uio.no/om/strategi/miljo/studier/milj\%C3\%B8studier-april2011.pdf

${ }^{16}$ I rettferdighetens navn vil jeg også framheve lektorprogrammet ved NMBU, som har hatt bærekraftig utvikling som gjennomgangstema i en årrekke og tatt til orde for en integrert, helhetlig og tverrfaglig tilnærming.
} 
som skulle gjennomsyre alle sektorer i samfunnet. Også utdanningen selv skal være gjennomsyret av spørsmålet om hvordan utviklingen kunne giøres mer bærekraftig (Finansdepartementet, 2008; Laumann, 2007). Vår felles framtid og Agenda 21 hevdet, som nevnt, at omlegging til en mer bærekraftig utvikling ikke ville være mulig uten å involvere utdanning. Men da det ble tid for implementering, ble det likevel sagt at Norge hadde gjort såpass mye allerede at ingen spesiell anstrengelse var nødvendig (Laumann, 2007).

To masteroppgaver ved Senter for Utvikling og Miljø (UiO) har studert oppfølgingen av FNs tiår for ESD (Raabs, 2010; Laumann, 2007).${ }^{17}$ Konklusjonen er i begge tilfeller nedslående: Det har vært vanskelig å finne skoler som har arbeidet med temaet, og det har vært svært vanskelig å finne informanter i det offentlige skoleverket - men lettere i Steinerskolene, ifølge Raabs (2010). ${ }^{18}$ Laumann, som har intervjuet ledende utdanningsbyråkrater så vel som lærere og elever, skrev i 2007 at:

The UN Decade of Education for Sustainable Development is not a priority [for the Norwegian UNESCO Commission], and there are no current or planned activities in relation to this initiative in Norway. The general atmosphere among Norwegian education authorities is that so much has already been achieved when it comes to education for sustainable development that to make a special effort within the UNESCO framework is not necessary (Laumann, 2007, s. 36-37).

Astrid Sandås, seniorrådgiver ved Utdanningsdirektoratet, ${ }^{19}$ sier i et intervju at det har vært en betydelig utfordring å integrere bærekraftig utvikling i skoleverket: «In the last twenty years it has almost been impossible to consider including environmental concerns in policy planning in Norway. There has been a strong focus on growth and increasing consumption» (Laumann, 2007, s. 41). Laumanns konklusjon er at FNs tiår for utdanning for bærekraftig utvikling har hatt liten eller ingen innvirkning på norsk utdanning på undersøkelsens tidspunkt (s. 37), noe som bekreftes av Andresen et al. i 2015.

Hva kan vi si om strategien for utdanning for bærekraftig utvikling (Kunnskapsdepartementet, 2012)? Det korte dokumentet er ikke så mye en strategi som en oppsummering av ulike tiltak, målformuleringer, ressurser og utfordringer for UBU-arbeid i barnehage, grunnopplæringen og lærerutdanningen. Når det gjelder grunnopplæringen, står det å lese at:

Skolens ansvar for å velge arbeidsmåter gir lærere gode muligheter til å vektlegge utdanning for bærekraftig utvikling i sin undervisning. Flere lærere rapporterer imidlertid at $ø \mathrm{kt}$ press på grunnleggende ferdigheter, vurdering og nasjonale prøver går på bekostning av arbeidsformer som støtter utdanning for bærekraftig utvikling.

\footnotetext{
${ }^{17}$ Interessant nok er begge studentene utenlandske (men lærte seg norsk for å gjennomføre arbeidet). Norge ble valgt ut fra et inntrykk av å være et slags foregangsland for bærekraftig utvikling og miljø, noe som ble relativt grundig avkreftet gjennom begge studiene.

${ }^{18}$ Steinerskolene, som har sin egen læreplan, har bærekraftig utvikling som del av sitt verdigrunnlag.

${ }^{19}$ Sandås er også en av tre forskere som bidro til evalueringen av tiåret for ESD (Andresen et al., 2015).
} 
Utfordringen er å se at utdanning for bærekraftig utvikling støtter fagspesifikk læring og at det ikke er en motsetning mellom utvikling av grunnleggende ferdigheter og utdanning for bærekraftig utvikling (Kunnskapsdepartementet, 2012, s. 10).

Det er uklart hva som menes med at «utfordringen er å se at ... det ikke er noen motsetning», all den tid erfaringene peker mot at motsetninger qua hindringer eksisterer i dagens skole. Det har vist seg å være krevende for lærere å skape rom til å arbeide med utdanning for bærekraftig utvikling i en skole preget av mange mål, og ikke minst, av målinger (Sinnes \& Jegstad, 2011). Strategien fastslår på sin side at «Forskning viser at når skolen og lærerne får god oppfølging i form av støtte og veiledning, er det lett å få til gode tverrfaglige samarbeidsprosjekter i tråd med målsetninger for utdanning for bærekraftig utvikling» (Kunnskapsdepartementet, 2012, s. 10). Den gir imidlertid ingen forslag til hvordan slik støtte kan oppnås, eller hvordan utdanning for bærekraftig utvikling kan integreres i skolens virksomhet som helhet. Budskapet om at bærekraftig utvikling er et viktig mål som støter mot betydelige utfordringer, ledsages altså ikke av noen strategi. Med slike styringsdokumenter er det kanskje ikke så overraskende at arbeidet for bærekraftig utvikling aldri kom av bakken i den norske skolen.

\section{Utdanning for barekraftig utvikling - et større perspektiv}

At utdanning er viktig, ja, sentralt for å skape en mer bærekraftig utvikling, står å lese $\mathrm{i}$ en rekke sammenhenger. ${ }^{20}$ Det gjenstår imidlertid å utrede hvordan en slik utvikling skal se ut i norsk skole, tilsvarende Att lära för hållbar utveckling (SOU 2004:104). I litteraturen om utdanning for bærekraftig utvikling skilles det ofte mellom det å lere om bærekraftig utvikling - jf. utvalgets omtale av «utfordringer knyttet til bærekraftig utvikling» (s. 62) - og en utdanning som er organisert for $\stackrel{a}{\circ}$ skape en bærekraftig utvikling (Sinnes, 2015). Det siste er selvfølgelig langt mer krevende, og vil nødvendigvis måtte utfordre de politiske og økonomiske institusjonene all den tid den eksisterende utviklingen $i k k e$ er bærekraftig.

I 2015 kom den første - etterlengtede - boka om utdanning for bærekraftig utvikling på norsk ved Astrid T. Sinnes (2015). Samme år kom Ludvigsenutvalgets rapport Fremtidens skole (NOU 2015:8), som tar for seg framtidige behov for opplæring og kompetanseutvikling. Utvalget tok her til orde for å gjøre bærekraftig utvikling til ett av tre overordnede, «flerfaglige temaer» som er «særlig viktige fremover». Disse må etter utvalgets mening være tydelige i læreplanverket, med egne kompetansemål på tvers av fag (NOU 2015:8, s. 49). Temaene må «styrkes», «være tydelige i læreplanverket» og behandles på en «systematisk måte» i flere fag

\footnotetext{
${ }^{20}$ Soria Moria-erklæringene fra den rød-grønne regjeringen Stoltenberg (I og II) kan nevnes i tillegg til de dokumentene som allerede er omtalt.

${ }^{21}$ Stortingsmeldingen Fag - Fordypning - Forståelse - En fornyelse av Kunnskapsløftet (Meld. St. 28 (2015-2016)) viderefører bærekraftig utvikling som ett av tre «temaer i fagfornyelsen», sammen med «demokrati og medborgerskap» og «folkehelse og livsmestring» (pkt. 1.3).
} 
(NOU 2015:8, s. 14;52;62). Det gjenstår likevel å se om temaet vil få gjennomslag, og på hvilken måte. ${ }^{21}$ Utvalget utdyper:

Opplæringen av barn og unge innebærer utvikling av en god forståelse av hvilken risiko klima- og miljøutfordringene innebærer. Like viktig er det at de erkjenner at alle har ansvar for aktiv og bevisst handling for bedre miljø. De må være motivert for klimabevisste valg både i dag og i fremtiden, og de må gis handlingsevne og -muligheter. Bærekraftig utvikling har en forankring i naturfag, men det er også flerfaglig og krever en flerfaglig tilnærming. Utvalget mener at bærekraftig utvikling bør styrkes i læreplanverket og integreres i flere fag, spesielt i samfunnsfagene og naturfagene (s. 50).

Med dette siste peker utvalget på en svakhet som har preget arbeidet med UBU i den norske skolen så langt. Prosjektene tilknyttet Den naturlige skolesekken har, som nevnt, ofte dreid seg om aktiviteter i skolens (mer eller mindre) naturlige nærmiljø (Andresen et al., 2015). Selv om intensjonen kanskje var en annen, har den norske tilnærmingen til utdanning for bærekraftig utvikling i praksis blitt for nært knyttet til natur- og miljøfag og uteskole, slik at det har vært vanskelig å få samfunnsfagene på banen. For å favne kompleksiteten i dagens miljø- og utviklingsproblemer, ikke minst med hensyn til klimaendringer, er imidlertid tverrfaglighet og systemforståelse etter manges syn helt nødvendig (Hulme, 2009; Kahn, 2010).

Laumann (2007) har studert læreplaner og lærebøker i natur- og samfunnsfag for ungdomstrinnet slik de var i 2007. Hun oppsummerer for samfunnsfagenes vedkommende: «In general, while the social science subject raises a range of societal questions, possibilities and challenges, it lacks focus on environmental and developmental issues. Overall, the curriculum aims to educate critical and reflecting students, but not in relation to sustainable development» (s. 64). I naturfagene finner hun et smalt perspektiv på naturfaglige emner, der samfunnsmessige og globale sammenhenger, som trolig kunne motivert elevene (ytterligere) i disse fagene, mangler (s. 61). Jeg vil legge til at en tilsvarende skjevhet finnes i pedagogikkfaget, der det mangler litteratur om emner som bærekraftig utvikling, klimaendringer og sosial endring med utgangspunkt i lokale (norske) forhold.

I Nord- og Sør-Amerika er situasjonen en annen. Nord-Amerikanske økopedagoger har for eksempel i lengre tid vært opptatt av at kunnskapssynet $i$ det vestlige utdanningssystemet bidrar til å opprettholde avmakt, dominans og (en falsk) splittelse mellom naturen og mennesket (se Bowers, 1997; Kahn, 2010; Orr, url/1991; Stone \& Barlow, 2005). David Orr, for eksempel, hevder at tradisjonelle (vestlige) undervisningsformer lærer elevene avmakt - at det ikke nytter å endre det bestående - og at det er en stor kløft mellom kunnskapen vi lærer i utdanningssystemet og «den virkelige verden» der handlingene foregår. USA og mange andre land har en rekke private institusjoner som har utviklet pedagogiske opplegg for en mer bærekraftig utvikling - men det finnes også eksempler innenfor det nordiske offentlige utdanningssystemet. Et interessant eksempel CEMUS, som ligger ved Universitetet $i$ Uppsala og det svenske landbruksuniversitetet; dette er et studentledet senter som arbeider genuint tverrfaglig innenfor en antiautoritær struktur. Hensikten er at 
studentene skal få erfare at det er liten avstand mellom det de lærer og det de kan gjøre (CEMUS, 2011, s. 29).

Det fins en rekke kreative prosjekter og initiativer som kan studeres for å utvikle nye tilnærminger til utdanning for bærekraftig utvikling, spesielt innenfor kunstfeltet og i krysningen mellom ulike felter som kunst/akademia. Men, som den norske fortellingen om Agenda $21 \mathrm{og}$ ESD/UBU har vist oss, er gode intensjoner og kreativitet ikke nok til å skape den type endringer det her er snakk om. Å skape en mer bærekraftig utvikling betyr, i praksis, å sette seg opp mot veldig sterke krefter (Klein, 2014). Kanskje er det nå på tide, for Norge og andre land, å innse at ministerpostene $i$ departementene for klima, miljø, barn og utdanning bør rustes med de sterkeste og mest erfarne ministrene, og at pedagogikken (og skolen) igjen ser til sin politiskkreative rolle, og ikke bare tilpasning til det som skal komme. Pedagogikken, som på 1970- og 80-tallet var virksom i blant annet miljøkampen, fredsbevegelsen osv. står i dag for ubrukte muligheter som brobygger og perspektivskaper.

Historien om Sveriges tilnærming til Agenda 21 og ESD viser også at enkeltpersoners innsats blir fruktbar når ulike institusjoner kan støtte, utfordre og inspirere hverandre. ${ }^{22}$ Ikke minst er det interessant å se hvordan målene for ESD ikke ser ut til å konkurrere med de andre målene i skoleverket (PISA/OECD-målene), men omtales side om side i nasjonale styringsdokumenter (Östman \& Östman, 2013, s. 90-91). Det kan etter mitt syn ikke være noen tvil om at utdanning for bærekraftig utvikling fortjener å forankres på høyeste nivå i utdanningssystemet og gjøres til gjenstand for seriøs - tverrfaglig - forskning. Det er tross alt vår felles framtid det står om.

\section{Biografi}

Ingerid Straume (f. 1963) er utdannet i psykologi, etikk og pedagogisk filosofi ved Universitetet i Oslo. Blant hennes faglige interesser er demokratisk og radikal politikk, miljø- og klimaspørsmål og pedagogisk filosofi. Hun har publisert en rekke artikler og bokkapitler, og vært redaktør for tre internasjonale antologier. Straume leder for tiden Akademisk skrivesenter ved Universitetsbiblioteket, Universitetet i Oslo, og skriver bok om pedagogisk filosofi og klimaendringer.

\section{Referanser}

Aall, C. (2000). Municipal Environmental Policy in Norway: from 'mainstream' policy to 'real' Agenda 21? Local Environment, 5(4), 451-465.

Andresen, Høgmo \& Sandås. (2015). Learning from ESD projects during the UN Decade in Norway. I R. Jucker \& R. Matar (Red.). Schooling for Sustainable Development in Europe. Concepts, Policies and Educational Experiences at the End of the UN Decade of Education for Sustainable Development (s. 241-256). Dordrecht: Springer.

Bjørnæs, T. \& Nordland, I. (2002). Local Agenda 21: Pursuing sustainable development at the local level. I W. M. Lafferty, M. Nordskag \& H. A. Aakre (Red.). Realizing Rio in Norway. Evaluative Studies of Sustainable Development. Oslo: ProSus.

Bowers, C. A. (1997). The Culture of Denial: Why the environmental movement needs a strategy for reforming universities and public schools. New York: SUNY.

Bregnballe, A. (2005). Når opplysning blir hindring - legfolk og fagfolk $i$ dialog om utviklings- og miljøpolitikk. Doktoravhandling, Institutt for statsvitenskap, Universitetet i Oslo, Oslo.

\footnotetext{
${ }^{22}$ Selv om Sverige stiller i fremste rekke i internasjonale samarbeid om ESD, er det fortsatt vanlig å høre svenske forskere hevde at mye gjenstår på dette området.
} 


\section{«Norge ligger på dette området langt fremme $i$ forhold til de fleste land»}

Bregnballe, A. (2007). New institutions are not sufficient. NIBR working paper 2007:116, s. 75-96. http:// www.hioa.no/extension/hioa/design/hioa/images/nibr/files/2007-116.pdf

CEMUS (2011). Transcending boundaries. How CEMUS is changing how we teach, meet and learn. Uppsala: Centrum för Miljö och Utvecklingsstudier i Uppsala.

Eide, E., Elgesem, D., Gloppen, S. \& Rakner, L. (Red.). (2014). Klima, medier og politikk. Oslo: Abstrakt.

Finansdepartementet (2008). Norges strategi for barekraftig utvikling. https://www.regjeringen.no/contentassets/ 16ff8fe9d838475ea987669856fae9b9/strategi-for-barekraftig-utvikling.pdf

Finansdepartementet (2005). Indicators for policies to enhance sustainable development. https://www.regjeringen. no/globalassets/upload/kilde/fin/bro/2005/0001/ddd/pdfv/246109-indicators.pdf

Gadotti, M. (2010). Reorienting education practices towards sustainability. Fournal of education for sustainable development. 4, (2), 203-201.

Gundersen, F. (1996). Framveksten av den norske miljøbevegelsen. I K. Strømsnes \& P. Selle (Red.). Miljøvernpolitikk og miljøvernorganisering mot år 2000. Oslo: Aschehoug.

Holm, T. (2015). Education for sustainable development and quality assurance in universities in China and the Nordic countries: a comparative study. fournal of cleaner production. 107, 529-537.

Hulme, M. (2009). Why we disagree about climate change. New York: Cambridge UP.

Jucker, R. \& Matar, R. (Red.). (2015). Schooling for Sustainable Development in Europe. Concepts, Policies and Educational Experiences at the End of the UN Decade of Education for Sustainable Development. Dordrecht: Springer.

Kahn, R. (2010). Critical Pedagogy, Ecoliteracy, \& Planetary Crisis: The Ecopedagogy Movement. New York: SUNY.

Klein, N. (2014). This Changes Everything. Capitalism vs. the climate. London: Allen Lane.

Kunnskapsdepartementet (2012). Kunnskap for en felles framtid. Revidert strategi for utdanning for berekraftig utvikling 2012-2015. Oslo: Det kongelige kunnskapsdepartement.

Knutsson, B. (2011). Curriculum in the Era of Global Development - Historical Legacies and Contemporary Approaches. Doktorsavhandling, Utbildningsvetenskapliga fakulteten, Gøteborgs Universitet.

Lafferty, W.M. \& Langhelle, O. (Red.). (1995). Barekraftig utvikling. Oslo: Gyldendal.

Lafferty, W.M., Aall, C. \& Seippel, Ø. (1998). Fra miljøvern til berekraftig utvikling $i$ norske kommuner Overgang fra MIK til Lokal Agenda 21. Rapport nr. 2/98. Oslo: ProSus.

Lafferty, W. M., Nordskag, M. \& Aakre, H. A. (2002). Realizing Rio in Norway. Evaluative Studies of Sustainable Development. Oslo: ProSus.

Lafferty, W. M., Knudsen, J. \& Mosvold Larsen, O. (2007). Pursuing sustainable development in Norway: the challenge of living up to Brundtland at home. European Environment, 17(3), 177-188.

Laumann, K. (2007). The Missing Story. Education for Sustainable Development in Norway. Masteroppgave, Senter for Utvikling og Miljø. Universitetet i Oslo, Oslo.

Lindseth, G. \& Bjørnæs, T. (2002) «Unyansert om miljøpolitikken», Samtiden, 2002, 4, 125-129.

Martiniussen, E. (2012). «De nye miljøpessimistene», kronikk i Morgenbladet 12. juli 2012.

Martiniussen, E. (2013). Drivhuseffekten. Klimapolitikken som forsvant. Oslo: Manifest.

Meld. St. 28 (2015-2016) Fag - Fordypning - Forståelse - En fornyelse av Kunnskapsloftet. Oslo: Kunnskapsdepartementet.

Miløøverndepartementet (1992). St. meld 13, 1992-93. FN konferansen om miljø og utvikling (UNCED). Oslo: Miljøverndepartementet.

Nationalkommitén för Agenda 21 och Habitat (2003) En hållbar framtid i sikte (SOU 2003:31). http://www. regeringen.se/contentassets/59fe59061e4e4861a6dd7579b720ca51/en-hallbar-framtid-i-sikte

NOU 2015:8. Fremtidens skole. Fornyelse av fag og kompetanse. Oslo: Departementenes servicesenter.

Nordgaar, K.M. (2011). Living in Denial. Climate Change, Emotions, and Everyday Life. Boston Mass: MIT Press.

Orr, D. (url/1991). What is education for? Six myths about about the foundations of modern education, and six new principles to replace them. Hentet 17.9.2016 fra http://www.context.org/iclib/ic27/orr/

Raabs, N. K. (2010). No child in the Norwegian woods? A study on education for sustainable development in Norwegian primary schooling. Masteroppgave, Senter for Utvikling og Miliø, Universitetet i Oslo, Oslo.

Sandvik, H. (2008). Public concern over global warming correlates negatively with national wealth. Climatic Change, 90(3), 333-341.

Sinnes, A. T. \& Jegstad, K. M. (2011). Utdanning for bærekraftig utvikling: To unge realfaglæreres møte med skolehverdagen. Norsk Pedagogisk Tidsskrift., 95(4), 248-259.

Sinnes, A. T. (2015). Utdanning for berekraftig utvikling: Hva, hvorfor og hvordan?. Oslo: Universitetsforlaget. 


\section{Ingerid S. Straume}

Sinnes, A. T. \& Eriksen, C. C. (2015). Education for Sustainable Development and International Student Assessments: Governing Education in Times of Climate Change. Global Policy. doi: http://dx.doi.org/10. 1111/1758-5899.12256

Sjaastad, J., Carlsten, T.C., Opheim, V. \& Jensen, F. (2014) Evaluering av Den naturlige skolesekken. Utdanning for bærekraftig utvikling på ulike læringsarenaer. NIFU-rapport 38/2014 http://www.udir.no/ globalassets/upload/forskning/2014/nifu-trykkerapport-38-2014-2.pdf

Stone, M.K. \& Barlow, Z. (Red.). (2005). Ecological literacy. Educating our children for a sustainable world. San Francisco: Sierra book club.

Straume, I. S. (2001). Miljøspørsmål som samfunnsproblem. Lokal Agenda 21 og politisering av offentligheten. ProSusrapport 1/2001. Oslo: ProSus.

Straume, I. S. (2002). Den avpolitiserende miljøpolitikken. Samtiden, 2002, 2, 51-59.

Straume, I. S. (2005). Depoliticising environmental politics: Sustainable development in Norway. I Torgerson, D. \& Paehlke R. (Red.). Managing leviathan: Environmental politics and the administrative state (s. 191-207). Peterborough Ont: Broadview.

Strømsnes, K. \& Selle, P. (1996). Innledning: Miljøvern som forskningsfelt. I Strømsnes, K. \& P. Selle (Red.). Miljøvernpolitikk og miljøvernorganisering mot år 2000. Oslo: Aschehoug.

UNECE Strategi for hållbar utveckling (2008). Stockholm: Utbildningsdepartementet. http://www.unece.org/ fileadmin/DAM/env/esd/strategytext/Strategy.Swedish.pdf

UNESCO (2008). Decade of Education for Sustainable Development. hentet 17.9.2016 fra http://www.desd.org/ about.html

Utbildningsdepartementet (2004). Att lära för hållbar utveckling (SOU 2004:104). http://www.regeringen.se/ rattsdokument/statens-offentliga-utredningar/2004/11/sou-2004104/

Utenriksdepartementet (2002). Nasjonal strategi for barekraftig utvikling. http://www.regjeringen.no/nb/dep/ud/ dok/rapporter_planer/planer/2002/nasjonal-strategi-for-barekraftig-utvikl-2.html?regj_oss=1\&id=448574

Utenriksdepartementet (2009). Miljø og bærekraftig utvikling (artikkel) http://www.regjeringen.no/nb/dep/ud/ tema/utviklingssamarbeid/miljo/miljo-og-barekraftig-utvikling.html?regj_oss $=1$ \&id=450368

Verdenskommisjonen for Miljø og Utvikling (1987) Vår felles framtid. Oslo: Tiden.

Vibe, V., Gloppen, S. \& Rakner, L. (2014). «Klimabistand». I E. Eide, D. Elgesem, S. Gloppen \& V. Rakner (Red.). Klima, medier og politikk (s. 157-175). Oslo: Abstrakt.

Östman, E. Aa. \& Östman, L. (2013) «Sweden», i UNESCO, National fourneys towards Education for Sustainable Development http://unesdoc.unesco.org/images/0022/002210/221008e.pdf 